\title{
Resolving environmental drivers of microbial community structure in Antarctic soils
}

\author{
JULIE L. SMITH ${ }^{1,2}$, JOHN E. BARRETT ${ }^{3}$, GÁBOR TUSNÁDY ${ }^{4}$, LÍDIA REJTÖ ${ }^{5}$ and S. CRAIG CARY ${ }^{1,6 *}$ \\ ${ }^{1}$ College of Marine and Earth Studies, University of Delaware, Lewes, DE 19958, USA \\ 2 current address: Marine Biological Laboratory, Woods Hole, MA 02543, USA \\ ${ }^{3}$ Department of Biological Sciences, Virginia Polytechnic Institute and State University, Blacksburg, VA 24061, USA \\ ${ }^{4}$ Alfréd Rényi, Mathematical Institute of the Hungarian Academy of Sciences, Budapest, Hungary \\ ${ }^{5}$ Department of Food and Resource Economics, University of Delaware, Newark, DE 19716, USA \\ ${ }^{6}$ Department of Biological Sciences, University of Waikato, Hamilton, New Zealand \\ *Corresponding author: caryc@udel.edu
}

\begin{abstract}
Antarctic soils are extremely cold, dry, and oligotrophic, yet harbour surprisingly high bacterial diversity. The severity of environmental conditions has constrained the development of multi-trophic communities, and species richness and distribution is thought to be driven primarily by abiotic factors. Sites in northern and southern Victoria Land were sampled for bacterial community structure and soil physicochemical properties in conjunction with the US and New Zealand Latitudinal Gradient Project. Bacterial community structure was determined using a high-resolution molecular fingerprinting method for 80 soil samples from Taylor Valley and Cape Hallett sites which are separated by five degrees of latitude and have distinct soil chemistry. Taylor Valley is part of the McMurdo Dry Valleys, while Cape Hallett is the site of a penguin rookery and contains ornithogenic soils. The influence of soil moisture, $\mathrm{pH}$, conductivity, ammonia, nitrate, total nitrogen and organic carbon on community structure was revealed using Spearman rank correlation, Mantel test, and principal components analysis. High spatial variability was detected in bacterial communities and community structure was correlated with soil moisture and $\mathrm{pH}$. Both unique and shared bacterial community members were detected at Taylor Valley and Cape Hallett despite the considerable distance between the sites.
\end{abstract}

Received 28 March 2010, accepted 31 August 2010

Key words: abiotic controls, ARISA, McMurdo Dry Valleys, ornithogenic

\section{Introduction}

Ice-free regions constitute only $0.3 \%$ of the Antarctic continental landmass (Ugolini \& Bockheim 2008) and host unique terrestrial ecosystems, including polar deserts, that are well suited to studies of abiotic controls over biodiversity. Organisms inhabiting these polar deserts experience very low temperatures, months of darkness and soils that are highly saline, nutrient-limited and among the most arid in the world (Barrett et al. 2006b). The severity of conditions has constrained the development of multi-trophic ecosystems and as a result, species abundance and distribution in polar deserts is driven primarily by abiotic factors (Hogg et al. 2006). Most organisms in Antarctic soils are microscopic and include bacteria, fungi, and algae, with nematodes as the top grazers (Wall \& Virginia 1999). Community structure is thought to be controlled mainly by the amount of biologically available liquid water, which is exacerbated by the persistent freezing temperatures and the high salt content of soils (Treonis et al. 1999, Hogg et al. 2006).

Despite the harsh setting, several recent molecular studies have revealed that Antarctic soils harbour surprisingly high bacterial diversity (Barrett et al. 2006a, Smith et al. 2006,
Yergeau et al. 2007, Niederberger et al. 2008), spanning as many as 14 different phyla (Cary et al. 2010). Most studies have focused on the McMurdo Dry Valleys in southern Victoria Land, the most expansive ice-free region in Antarctica, and have shown that these mineral soils are dominated by Acidobacteria, Actinobacteria, and Bacteroidetes (Cary et al. 2010). Smaller ice-free regions in northern Victoria Land (e.g. a dry cirque in the Admiralty Mountains informally known as Luther Vale) harbour Deinococcus/Thermus and the Gammaproteobacteria/Xanthomonas (Niederberger et al. 2008), while actively penguin-colonized ornithogenic soils at Cape Hallett and Cape Bird are dominated by spore-forming Firmicutes and the Gammaproteobacteria/Psychrobacter (Aislabie et al. 2009). In contrast, the dominant groups in formerly penguin-colonized soils at Cape Hallett shifted to Actinobacteria and Xanthomonas of the Gammaproteobacteria (Aislabie et al. 2009).

This study compares physicochemically distinct soils from Taylor Valley in the McMurdo Dry Valleys of southern Victoria Land and Cape Hallett in northern Victoria Land, which are separated by five degrees of latitude. Taylor Valley has alkaline mineral soils that receive less than $10 \mathrm{~cm}$ water equivalent per year (Campbell \& Claridge 1982, 
Doran et al. 2002). The limited organic carbon in these soils comes from the modern photosynthetic activity of cyanobacteria, lichens and mosses that colonize wetter areas and the ancient organic sediments deposited when the valley was inundated by the palaeolake Washburn during the Last Glacial Maximum (Burkins et al. 2000). Taylor Valley soils retain salts from past and recent lacustrine intrusions and accumulate additional salts through prolonged weathering and deposition of atmospherically derived salts (Michalski et al. 2005, Barrett et al. 2009). In contrast, Cape Hallett soils have formed on basaltic screes that receive $18 \mathrm{~cm}$ water equivalent per year (Duphorn 1981) and are heavily influenced by the proximity of marine habitats and by colonies of Adélie penguins (Pygoscelis adeliae Hombron $\&$ Jacquinot) and skuas (Catharacta maccormicki Saunders).

This study builds upon two previous studies (Barrett et al. 2006a, Niederberger et al. 2008) associated with the Latitudinal Gradient Project (LGP) (Howard-Williams et al. 2006) which examined microbial communities and soil chemistry in northern and southern Victoria Land. Barrett et al. (2006a) used the molecular fingerprinting method of DGGE (denaturing gradient gel electrophoresis) to compare microbial assemblages in northern and southern Victoria Land soils. The DGGE method utilizes sequence differences in variable regions of the $16 \mathrm{~S}$ rRNA gene to create a profile of the bacterial community. This study showed that the richness of the community did not differ between sites, but the different sites had distinct communities comprised of different types of bacteria. While the DGGE profiles were not correlated with any one soil physicochemical property, soils with similar water and nutrient content had similar microbial fingerprints (Barrett et al. 2006a). In a second study, Niederberger et al. (2008) sequenced 16S rRNA genes, allowing the phylogenetic identification of bacteria from four northern Victoria Land soil samples collected from Luther vale (Luther vale is a dry cirque near Cape Hallett that does not contain ornithogenic soils). Niederberger et al. (2008) found high diversity and high spatial variability in samples collected from within $200 \mathrm{~m}$ of each other. In these Luther vale samples, drier, low productivity soils were dominated by Deinococcus/Thermus species, while high productivity soils were dominated by Xanthomonas species (Niederberger et al. 2008).

In an effort to resolve the abiotic-biotic interactions, we used a more sensitive, high throughput molecular fingerprinting method, bacterial ARISA (automated ribosomal intergenic spacer analysis), which utilizes size polymorphisms in the 16S-23S ribosomal spacer region (Fisher \& Triplett 1999). ARISA provides higher resolution of bacterial community structure through the analysis of the highly variable spacer region using capillary electrophoresis rather than gel electrophoresis (Nocker et al. 2007). In addition, a variety of multi-variate statistics were used to clearly determine which environmental parameters influenced community structure.

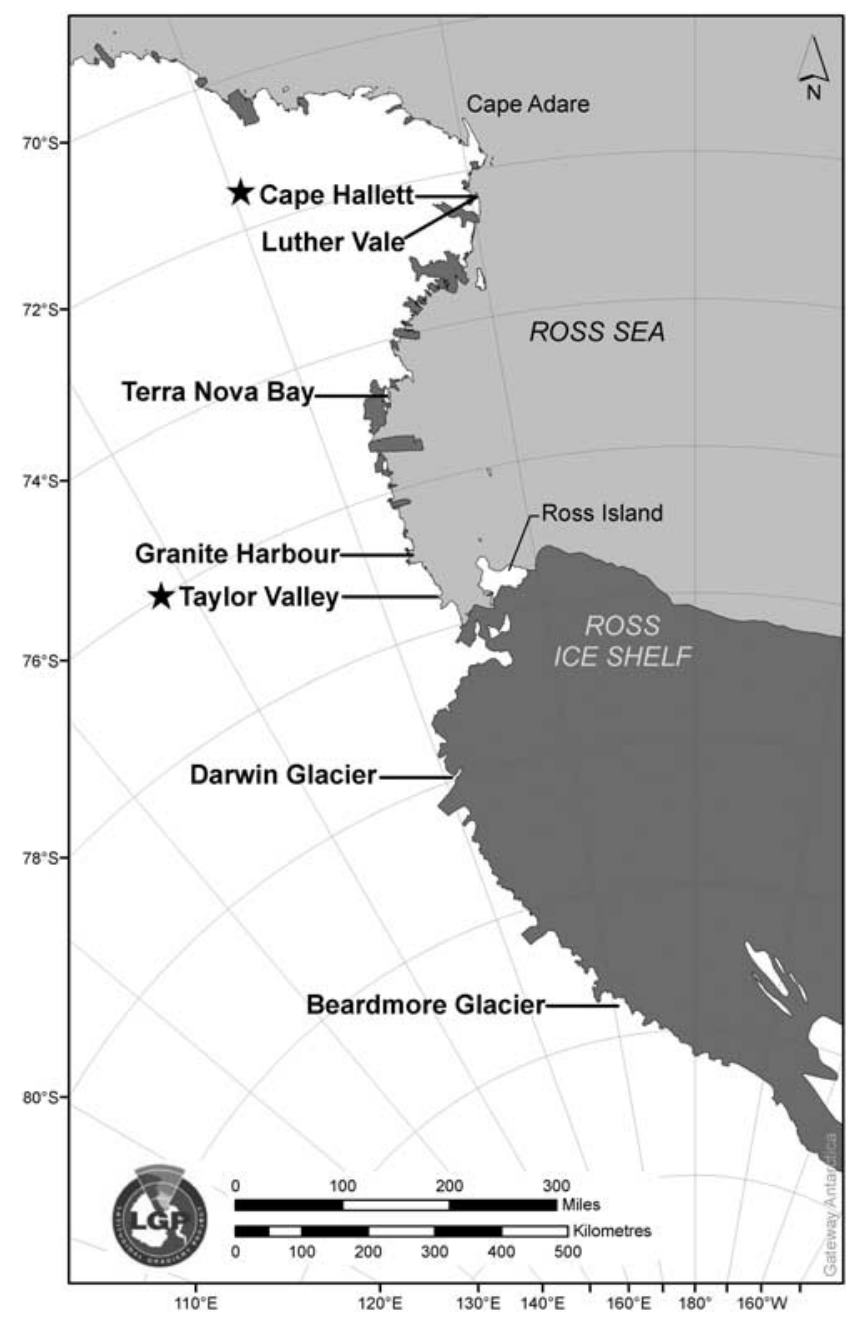

Fig. 1. Map of Antarctic locations studied through the Latitudinal Gradient Project using the Antarctic Digital Database (ADD) datasets. This study compared soils from Cape Hallett $\left(72^{\circ} 19^{\prime} \mathrm{S}, 170^{\circ} 13^{\prime} \mathrm{E}\right)$ in northern Victoria Land and Taylor Valley $\left(77^{\circ} \mathrm{S}, 162^{\circ} \mathrm{E}\right)$ in southern Victoria Land.

\section{Materials and methods}

\section{Sample collection and analysis of soil chemistry}

Mineral soil samples were collected in the summer of 2004-05 from two locations in Antarctica: Taylor Valley $\left(77^{\circ} \mathrm{S}, 162^{\circ} \mathrm{E}\right)$, in the McMurdo Dry Valleys in southern Victoria Land and Cape Hallett ( $\left.72^{\circ} 19^{\prime} \mathrm{S}, 170^{\circ} 13^{\prime} \mathrm{E}\right)$, an icefree coastal region in northern Victoria Land (Fig. 1). Cape Hallett soils were collected from moss, algae and lichen dominated surfaces not currently occupied by penguin nests, though stable isotopic signatures of organic matter in this vicinity indicate that ornithogenic influences on soils are ubiquitous (Barrett et al. 2006a). Both locations were divided a priori into high productivity and low productivity areas based on the relative abundance of visible primary producers (cyanobacteria and bryophytes) on the soil surface as previously described (Barrett et al. 2006a, 
Table I. Average physicochemical properties of soils from high and low productivity sites in Cape Hallett and Taylor Valley. The standard deviation is given in parentheses. Each site includes 20 samples collected from four transects. For each parameter, significantly different $(P<0.01)$ values determined by 2-way ANOVA and Tukey tests are indicated by superscript letters. $\mathrm{CHH}=\mathrm{Cape}$ Hallett, high productivity, $\mathrm{CHL}=\mathrm{Cape}$ Hallett, low productivity, TVH = Taylor Valley, high productivity, TVL = Taylor Valley, low productivity.

\begin{tabular}{|c|c|c|c|c|c|c|c|c|}
\hline Site & $\begin{array}{c}\text { Soil moisture } \\
(\%)\end{array}$ & $\mathrm{pH}$ & $\begin{array}{l}\text { Conductivity } \\
\left(\mu \mathrm{S} \mathrm{cm}^{-1}\right)\end{array}$ & $\begin{array}{l}\text { Ammonia } \\
\left(\mu \mathrm{gg}^{-1}\right)\end{array}$ & $\begin{array}{l}\text { Nitrate } \\
\left(\mu g g^{-1}\right)\end{array}$ & $\begin{array}{l}\text { Total soil } \mathrm{N} \\
\quad\left(\mathrm{mg} \mathrm{g}^{-1}\right)\end{array}$ & $\begin{array}{c}\text { Organic C } \\
\left(\mathrm{mg} \mathrm{g}^{-1}\right)\end{array}$ & $\mathrm{C}: \mathrm{N}$ \\
\hline $\mathrm{CHH}$ & $\begin{array}{c}13.48 \\
( \pm 3.72)^{\mathbf{A}}\end{array}$ & $\begin{array}{c}5.73 \\
( \pm 0.48)^{\mathbf{A}}\end{array}$ & $\begin{array}{c}75.99 \\
( \pm 66.49)^{\mathbf{A}}\end{array}$ & $\begin{array}{c}55.99 \\
( \pm 86.24)^{\mathbf{A}}\end{array}$ & $\begin{array}{c}6.45 \\
( \pm 5.38)^{\mathbf{A}}\end{array}$ & $\begin{array}{c}2.47 \\
( \pm 1.60)^{\mathbf{A}}\end{array}$ & $\begin{array}{c}14.68 \\
( \pm 8.53)^{\mathbf{A}}\end{array}$ & $\begin{array}{c}6.12 \\
( \pm 0.42)^{\mathbf{A}}\end{array}$ \\
\hline $\mathrm{CHL}$ & $\begin{array}{c}10.62 \\
( \pm 5.04)^{\mathbf{A}}\end{array}$ & $\begin{array}{c}5.54 \\
( \pm 0.32)^{\mathbf{A}}\end{array}$ & $\begin{array}{c}36.72 \\
( \pm 18.87)^{\mathbf{A}}\end{array}$ & $\begin{array}{c}3.08 \\
( \pm 2.70)^{\mathbf{B}}\end{array}$ & $\begin{array}{c}2.08 \\
( \pm 1.22)^{\mathbf{B}}\end{array}$ & $\begin{array}{c}1.49 \\
( \pm 0.97)^{\mathbf{B}}\end{array}$ & $\begin{array}{c}9.52 \\
( \pm 6.18)^{\mathbf{B}}\end{array}$ & $\begin{array}{c}6.37 \\
( \pm 0.39)^{\mathbf{A}}\end{array}$ \\
\hline TVH & $\begin{array}{c}4.65 \\
( \pm 4.83)^{\mathbf{B}}\end{array}$ & $\begin{array}{c}8.73 \\
( \pm 0.69)^{\mathbf{B}}\end{array}$ & $\begin{array}{c}108.73 \\
( \pm 97.02)^{\mathbf{A}}\end{array}$ & $\begin{array}{c}0.18 \\
( \pm 0.18)^{\mathbf{B}}\end{array}$ & $\begin{array}{c}2.10 \\
( \pm 4.31)^{\mathbf{B}}\end{array}$ & $\begin{array}{c}0.09 \\
( \pm 0.03)^{\mathbf{B}}\end{array}$ & $\begin{array}{c}0.35 \\
( \pm 0.18)^{\mathrm{C}}\end{array}$ & $\begin{array}{c}4.20 \\
( \pm 2.05)^{\mathbf{B}}\end{array}$ \\
\hline TVL & $\begin{array}{c}4.59 \\
( \pm 8.47)^{\mathbf{B}}\end{array}$ & $\begin{array}{c}9.45 \\
( \pm 0.37)^{\mathbf{C}}\end{array}$ & $\begin{array}{c}251.42 \\
( \pm 273.27)^{\mathbf{B}}\end{array}$ & $\begin{array}{c}0.16 \\
( \pm 0.18)^{\mathbf{B}}\end{array}$ & $\begin{array}{c}2.58 \\
( \pm 4.49)^{\mathbf{B}}\end{array}$ & $\begin{array}{c}0.08 \\
( \pm 0.03)^{\mathbf{B}}\end{array}$ & $\begin{array}{c}0.29 \\
( \pm 0.16)^{\mathrm{C}}\end{array}$ & $\begin{array}{c}3.98 \\
( \pm 2.02)^{\mathbf{B}}\end{array}$ \\
\hline
\end{tabular}

Niederberger et al. 2008). Four replicate transects (10 m in length) were established in a south to north direction for each high and low productivity site at each location, for a total of sixteen transects. Five samples were collected along each transect at 2, 3, 5, 7 and $8 \mathrm{~m}$ from the origin. The same positions along adjacent transects were treated as replicates. Soil samples were collected aseptically to a depth of $10 \mathrm{~cm}$. The samples were homogenized and stored at $-80^{\circ} \mathrm{C}$. Soil physicochemical parameters including gravimetric soil moisture, $\mathrm{pH}$, conductivity, ammonia, nitrate, total nitrogen and organic carbon were measured (Barrett et al. 2006a).

\section{DNA extraction and amplification of ribosomal intergenic spacer region}

Genomic DNA was extracted from soil samples using a bead beater protocol (Barrett et al. 2006a). Prior to amplification, DNA extractions were diluted $1: 100$ or 1:200 in 0.1X TE buffer to minimize PCR inhibition by co-extractants. The 16S-23S intergenic spacer region was amplified from the extracted community DNA using the primers ITSF (5'-GTCGTAACAAGGTAGCCGTA-3') and HEX-labelled ITSReub (5'-GCCAAGGCATCCACC-3') (Cardinale et al. 2004). Each reaction mixture contained $1 X$ PCR buffer (Sigma), $2.5 \mathrm{mM} \mathrm{MgCl}_{2}, 1.5 \mathrm{U}$ of Jumpstart Taq DNA polymerase (Sigma), $0.2 \mathrm{mM}$ (each) dNTP, and $0.25 \mu \mathrm{M}$ (each) primer in a final volume of $25 \mu$ l. Amplification was performed with a PTC-200 Programmable Thermal Controller (MJ Research, Inc.) as follows: $94^{\circ} \mathrm{C}$ for $3 \mathrm{~min}$, followed by 30 cycles of $94^{\circ} \mathrm{C}$ for $45 \mathrm{~s}, 55^{\circ} \mathrm{C}$ for $1 \mathrm{~min}, 72^{\circ} \mathrm{C}$ for $2 \mathrm{~min}$, and a final extension at $72^{\circ} \mathrm{C}$ for $7 \mathrm{~min}$. Amplification quality was evaluated through visualization on a $1 \%$ agarose gel stained with ethidium bromide. For each soil sample, three $25 \mu \mathrm{l}$ reactions were pooled. The pooled PCR products were cleaned by ethanol precipitation and concentrated by resuspension in $20 \mu \mathrm{l}$ of sterile $\mathrm{H}_{2} \mathrm{O}$.

Community profiles were generated by automated ribosomal intergenic spacer analysis (ARISA). For ARISA, $1 \mu l$ of cleaned and concentrated PCR product and $1 \mu l$ of a ROX-labelled custom internal size standard with fragments up to $1600 \mathrm{bp}$ (BioVentures) were separated by capillary electrophoresis on an ABI 3130xl Genetic Analyzer (Applied Biosystems) using POP-4 polymer (Perkin-Elmer) and a $50 \mathrm{~cm}$ capillary. Electrophoresis runs were conducted for $2 \mathrm{hr} 45 \mathrm{~min}$ with an injection voltage of $1.6 \mathrm{kV}$, injection time of $15 \mathrm{sec}$, run voltage of $7.5 \mathrm{kV}$, and a capillary temperature of $60^{\circ} \mathrm{C}$. Only peaks with a threshold of 50 fluorescence units or greater were considered. ARISA fragment lengths (AFL) from each soil sample were analysed and exported from ABI GeneMapper v3.7 (Applied Biosystems) and converted to presence/absence data in Microsoft Excel. To minimize error introduced by imprecise capillary electrophoresis, fragment sizes were binned (Hewson \& Fuhrman 2006).

\section{Statistical analysis}

Soil chemistry and ARISA data were analysed by 2-way analysis of variance (ANOVA), Tukey tests, and principal components analysis using XLSTAT 2009 (Addinsoft, New York, USA). Bacterial community structure was analysed using Primer 6 (Primer-E Ltd, Plymouth, UK). First, the presence or absence of binned AFLs (ARISA fragment lengths) was used to develop a similarity matrix based on the Bray-Curtis coefficient (Legendre \& Legendre 1998). The similarity of bacterial communities, grouped by location and productivity type, was assessed by an analysis of similarity (ANOSIM) which produces an $R$-statistic for each pair of groups where an $R$-statistic of one means that all of the most similar samples are in the same group and an $R$-statistic of zero means there is no difference between groups (Clarke 1993). The significance of the $R$-statistic was tested by Monte Carlo randomization with 999 permutations. A significant $R$-statistic indicates that samples within groups are more similar than would be expected by random chance. The relationship among individual bacterial community profiles was visualized with a two-dimensional multidimensional scaling (MDS) ordination based on 1000 restarts. An agglomerative, hierarchical clustering of Bray-Curtis similarities was used to designate clusters of $20 \%$ similarity.

The effect of abiotic soil properties on the bacterial community profiles was assessed by two methods. First, 


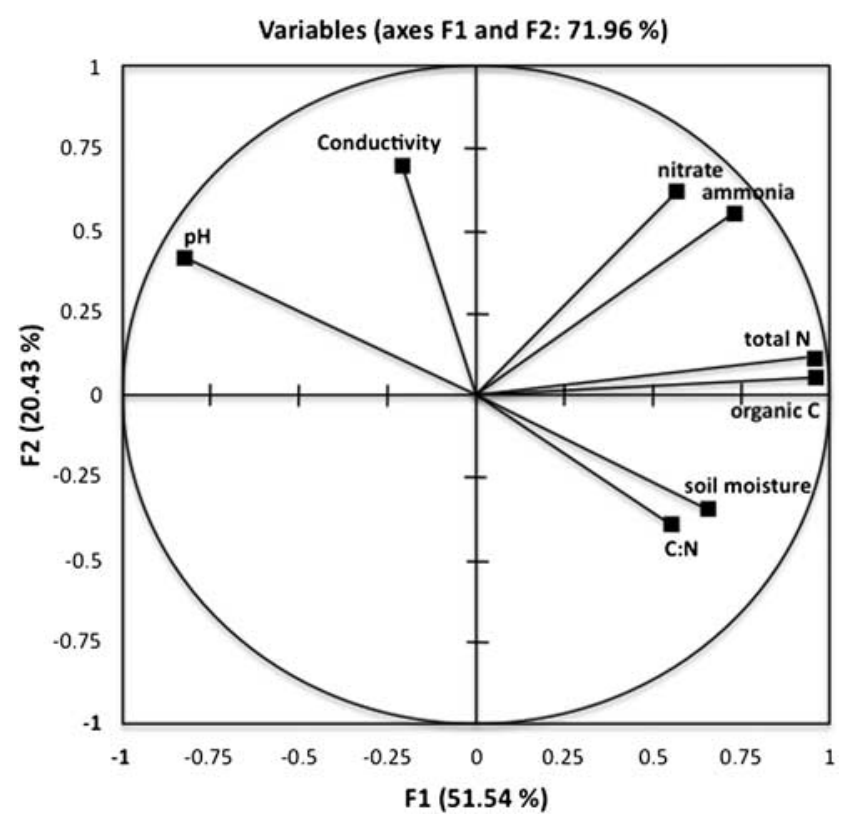

Fig. 2. Principal components analysis plot of soil chemistry data.

a Mantel test (Dietz 1983) was performed with 10000 permutations to compare the Gower similarity matrix (Gower 1971) of all eight soil properties and the Bray-Curtis similarity matrix of bacterial community profiles using XLSTAT 2009. The Mantel test determines whether the two matrices are correlated. Second, the BEST analysis method of Primer 6 (Clarke \& Gorley 2006) was used to determine which abiotic factors best explain the bacterial community structure. All eight soil variables except $\mathrm{pH}$ were $\log$ transformed and a similarity matrix was determined by Euclidean distance. The agreement between the biotic and abiotic similarity matrices was determined by Spearman's rank correlation performed with 999 permutations using the BEST analysis method.

\section{Results}

\section{Physicochemical characteristics}

Soil moisture levels ranged from less than $1 \%$ to $18 \%$, with significantly higher soil moisture in Cape Hallett soils than

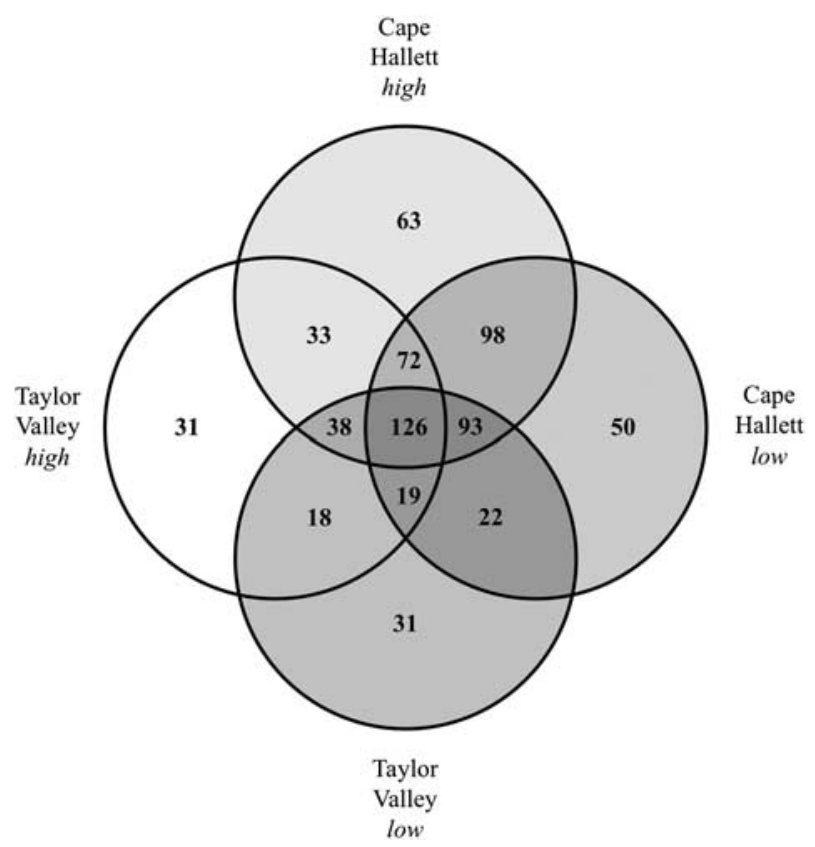

Fig. 3. Venn diagram illustrating the distribution of 724 bacterial ARISA fragments among soil samples in high and low productivity areas in Taylor Valley and Cape Hallett. Not shown: 14 AFLs shared by Cape Hallett low and Taylor Valley high productivity samples, 16 AFLs shared by Cape Hallett high and Taylor Valley low productivity samples.

in Taylor Valley soils (Table I). Taylor Valley soils had an average $\mathrm{pH}$ of 9.1, which was significantly more alkaline $(P<0.05)$ than Cape Hallett soils, with an average $\mathrm{pH}$ of 5.6 (Table I). Conductivity ranged from 23 to $530 \mu \mathrm{S} \mathrm{cm}^{-1}$, with significantly higher conductivity in Taylor Valley low productivity (TVL) soils than in all other soils (Table I). Cape Hallett high productivity soils had significantly higher levels of ammonia, nitrate, and total nitrogen than all other sites (Table I). Both Cape Hallett high (CHH) and low (CHL) productivity soils had significantly higher levels of organic carbon than the Taylor Valley soils (Table I). Carbon to nitrogen ratios ranged from 2.5:1 to 6.5:1, with significantly larger C:N ratio in Cape Hallett soils than in Taylor Valley soils (Table I).

Table II. Pearson correlation matrix of physicochemical soil properties. Values in bold are different from zero with a significance level alpha $=0.05$.

\begin{tabular}{lcccccrrrr}
\hline Variables & $\begin{array}{c}\text { soil } \\
\text { moisture }\end{array}$ & $\mathrm{pH}$ & conductivity & ammonia & nitrate & organic C & total N & C:N & \#AFLs/site \\
& & & & & & & & \\
\hline soil moisture & $\mathbf{1}$ & $\mathbf{- 0 . 5 6 0}$ & $\mathbf{- 0 . 2 3 0}$ & $\mathbf{0 . 2 3 4}$ & 0.159 & $\mathbf{0 . 5 7 4}$ & $\mathbf{0 . 5 4 9}$ & $\mathbf{0 . 3 9 7}$ \\
pH & $\mathbf{- 0 . 5 6 0}$ & $\mathbf{1}$ & $\mathbf{0 . 4 1 0}$ & $\mathbf{- 0 . 3 5 5}$ & -0.207 & $\mathbf{- 0 . 7 4 6}$ & $\mathbf{- 0 . 7 1 7}$ & $\mathbf{- 0 . 6 1 9}$ & $\mathbf{- 0 . 4 3 3}$ \\
conductivity & $\mathbf{- 0 . 2 3 0}$ & $\mathbf{0 . 4 1 0}$ & $\mathbf{1}$ & 0.087 & 0.206 & -0.159 & -0.137 & -0.114 & $\mathbf{- 0 . 2 9 7}$ \\
ammonia & $\mathbf{0 . 2 3 4}$ & $\mathbf{- 0 . 3 5 5}$ & 0.087 & $\mathbf{1}$ & $\mathbf{0 . 6 6 8}$ & $\mathbf{0 . 7 0 7}$ & $\mathbf{0 . 7 5 7}$ & 0.088 & 0.132 \\
nitrate & 0.159 & -0.207 & 0.206 & $\mathbf{0 . 6 6 8}$ & $\mathbf{1}$ & $\mathbf{0 . 4 9 5}$ & $\mathbf{0 . 5 2 3}$ & 0.178 & -0.060 \\
organic C & $\mathbf{0 . 5 7 4}$ & $\mathbf{- 0 . 7 4 6}$ & -0.159 & $\mathbf{0 . 7 0 7}$ & $\mathbf{0 . 4 9 5}$ & $\mathbf{1}$ & $\mathbf{0 . 9 9 5}$ & $\mathbf{0 . 4 1 4}$ & $\mathbf{0 . 3 0 5}$ \\
total N & $\mathbf{0 . 5 4 9}$ & $\mathbf{- 0 . 7 1 7}$ & -0.137 & $\mathbf{0 . 7 5 7}$ & $\mathbf{0 . 5 2 3}$ & $\mathbf{0 . 9 9 5}$ & $\mathbf{1}$ & $\mathbf{0 . 3 6 6}$ & $\mathbf{0 . 2 8 8}$ \\
C:N & $\mathbf{0 . 3 9 7}$ & $\mathbf{- 0 . 6 1 9}$ & -0.114 & 0.088 & 0.178 & $\mathbf{0 . 4 1 4}$ & $\mathbf{0 . 3 6 6}$ & $\mathbf{1}$ \\
\#AFLs/site & $\mathbf{0 . 2 9 8}$ & $\mathbf{- 0 . 4 3 3}$ & $\mathbf{- 0 . 2 9 7}$ & 0.132 & -0.060 & $\mathbf{0 . 3 0 5}$ & $\mathbf{0 . 2 8 8}$ & $\mathbf{0 . 2 2 8}$ & $\mathbf{0 . 2 2 8}$ \\
\hline
\end{tabular}




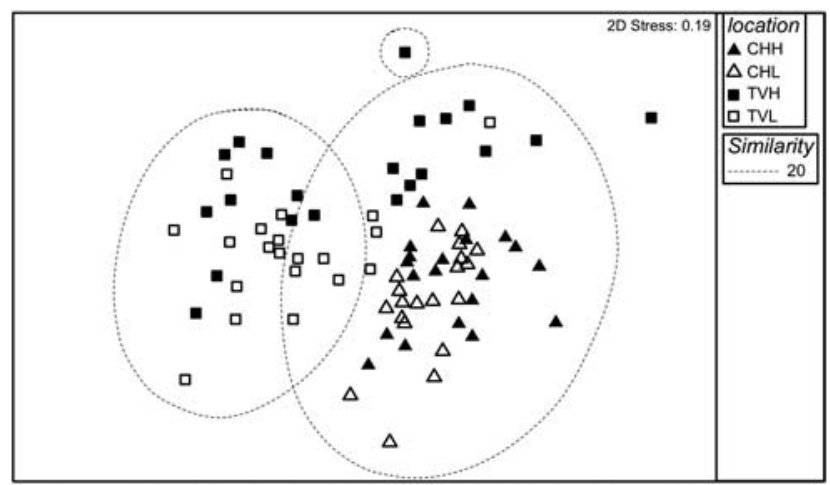

Fig. 4. Multidimensional scaling (MDS) plot generated from Bray-Curtis similarity index based on the presence or absence of bacterial ARISA fragment lengths (AFLs) in Cape Hallett (triangles) and Taylor Valley (squares) soil samples. Closed symbols are samples designated high productivity, open symbols are low productivity. The dashed line represents $20 \%$ similarity based on agglomerative, hierarchical clustering of Bray-Curtis similarities.

Principal components analysis (PCA) exhibited covariation between soil physicochemical properties. The first two principal components accounted for $72 \%$ of the variation (Fig. 2). The largest factor loadings for the first component were organic $\mathrm{C}(21 \%)$, total $\mathrm{N}(21 \%)$, ammonia $(17 \%), \mathrm{pH}(17 \%)$, and soil moisture (11\%). The largest factor loadings for the second component were conductivity (26\%), nitrate $(25 \%)$, and ammonia (17\%). Pearson correlation analysis showed that the nutrients were all positively correlated (ammonia, nitrate, total N, organic C) (Table II). Soil moisture was positively correlated with organic C, total $\mathrm{N}$, and $\mathrm{C}: \mathrm{N}$ and negatively correlated with $\mathrm{pH}$ and conductivity. Levels of $\mathrm{pH}$ were also negatively correlated with organic $\mathrm{C}$, total $\mathrm{N}$, and $\mathrm{C}: \mathrm{N}$.

Table III. Analysis of similarity (ANOSIM) between bacterial communities in Cape Hallett and Taylor Valley soils designated high or low productivity a priori. An R-statistic of one indicates that samples within groups are more similar than samples between groups and an $R$-statistic of zero indicates that there is no difference between groups. The significance of the $R$-statistic was tested by Monte Carlo randomization with 999 permutations. Significant R-statistics mean that samples within groups are more similar than expected by chance alone. $\mathrm{CHH}=\mathrm{Cape}$ Hallett, high productivity, $\mathrm{CHL}=$ Cape Hallett, low productivity, $\mathrm{TVH}=$ Taylor Valley, high productivity, $\mathrm{TVL}=$ Taylor Valley, low productivity.

\begin{tabular}{lcc}
\hline Groups & $R$-statistic & $P$-value \\
\hline CHH, TVL & 0.622 & 0.001 \\
CHL, TVL & 0.591 & 0.001 \\
CHL, TVH & 0.522 & 0.001 \\
CHH, TVH & 0.479 & 0.001 \\
TVH, TVL & 0.18 & 0.004 \\
CHH, CHL & 0.134 & 0.002 \\
\hline
\end{tabular}

\section{Bacterial community profiles}

Each soil sample contained 9 to 147 (average $=51$ ) ARISA fragment lengths (AFLs). Fragment sizes ranged from 128 basepairs (bp) in length to $1315 \mathrm{bp}$, with $80 \%$ of the peaks falling within 284 to $727 \mathrm{bp}$. There was no significant difference in the number of AFLs found at most transect positions (data not shown). However, the transect position with the highest average number of AFLs (CHH1), was significantly different $(P<0.05)$ from the transect positions with the lowest number of AFLs (TVH2, TVH3, TVH5, TVL4, TVL5). A total of 724 binned AFLs were found, with many AFLs shared between both high and low productivity transects at Cape Hallett and Taylor Valley (Fig. 3). Almost $60 \%$ of the AFLs were found in at least one sample from both Cape Hallett and Taylor Valley and 17\% of the AFLs were found in at least one sample from all four location + productivity types (Cape Hallett high, Cape Hallett low, Taylor Valley high, Taylor Valley low). However, no individual AFL was found in all 80 soil samples and the most frequently occurring AFL was only found in 38 of the 80 samples. Each AFL was found in an average of six soil samples.

Multidimensional scaling (MDS) of binned AFLs showed that Cape Hallett microbial communities clustered together while Taylor Valley communities showed more variability, regardless of a priori designations of productivity (Fig. 4). An analysis of similarity (ANOSIM) showed that bacterial communities were similar in Cape Hallett low and high productivity soils (Table III). Likewise, the bacterial communities in Taylor Valley low and high productivity soils were similar (Table III).

\section{Linking physicochemical characteristics and bacterial community profiles}

Pearson correlation analysis of individual soil chemistry parameters and the number of AFLs per soil sample revealed only weak correlations (Table II). A Mantel test between the Gower similarity matrix of soil properties and the Bray-Curtis similarity matrix from binned AFLs showed that the matrices were positively correlated $(r=0.207, P<0.0001)$. This indicates that soils with similar physiochemical properties also contained similar bacterial assemblages. The BEST analysis showed the highest correlation $(\rho=0.564)$ between the bacterial community structure of all 80 soil samples with the abiotic factors, $\mathrm{pH}$ and soil moisture $(P<0.001)$.

\section{Discussion}

In agreement with two previous studies (Barrett et al. 2006a, Niederberger et al. 2008) of microbial diversity and soil chemistry in Antarctic soils, we found high spatial variability and incidence of correlations between the bacterial community and soil chemical parameters. The current study is unique in examining Cape Hallett soils, 
which are shaped by coastal and ornithogenic influences, and in the use of a high-resolution molecular fingerprinting method, ARISA. This study yielded an average of 51 peaks per soil sample, compared to an average of 10 DGGE bands from the same Taylor Valley soils (Barrett et al. 2006a). The number of DGGE bands was not significantly different among sites in Taylor Valley and Luther vale (Barrett et al. 2006a), whereas the number of ARISA fragment lengths was significantly different among one site in Cape Hallett and some sites in Taylor Valley.

Like other PCR-based fingerprinting methods, ARISA does not detect some members of the microbial community, especially those in very low abundance. However, the high throughput capacity of the ARISA technique allows many more soil samples to be processed than could be achieved by producing $16 \mathrm{~S}$ rRNA gene clone libraries or through culture-based methods (both of which have their own biases), allowing a more powerful statistical analysis of community and physicochemical data. The ARISA method provides a higher resolution image of bacterial community structure than DGGE due to the increased polymorphisms of the intergenic spacer region and the increased sensitivity of capillary electrophoresis over gel electrophoresis (Nocker et al. 2007). One drawback of the ARISA technique compared to DGGE, however, is that phylogenetic identity cannot be assigned to electropherogram peaks.

Each ARISA fragment length (AFL) can be considered an operational taxonomic unit (OTU), although different organisms could potentially have the same length ITS region, albeit with different nucleotide sequences. Conversely, heterogeneity in the rRNA operon within one organism could appear as multiple peaks in the electropherogram. Despite the fact that one AFL does not always equal one "species" of bacteria, differences in ARISA profiles reflect true differences in community composition (Green et al. 2004) and provide a rapid and repeatable assessment that can be applied to a large number of samples. The OTUs identified by ARISA have also been shown to be ecologically relevant as demonstrated in a study of the San Pedro Ocean Time Series in which subsets of the marine bacterioplankton exhibited strong, repeatable temporal patterns (Fuhrman et al. 2006). In this study, community composition was predictable from abiotic and biotic factors, indicating that not only are these communities structured by the environment, but also that the communities contain specialized taxa that are not ecologically redundant. If the community structure did not have a detectable pattern with respect to environmental factors, it could be inferred that the community was well dispersed and members were functionally interchangeable. While the use of ARISA profiles does not identify the functional groups in Antarctic soil communities, there was a detectable pattern in the bacterial communities and significant correlations with abiotic factors. Cape Hallett soils had similar bacterial communities and Taylor Valley soils had similar bacterial communities, with only moderate overlap in taxa among individual soil samples. This suggests that bacteria could be dispersed throughout ice-free regions in Victoria Land, but the very distinct soil properties of Cape Hallett and Taylor Valley create locally selected communities.

The most dramatic difference between Cape Hallett and Taylor Valley soils is in $\mathrm{pH}$, an environmental variable which can exhibit strong selective pressure on bacteria (Padan et al. 1981). Most microorganisms have an intracellular $\mathrm{pH}$ within one unit of neutral (Madigan \& Martinko 2006) and maintain this internal $\mathrm{pH}$ through the use of proton pumps and the internal production of acids by fermentous bacteria (Padan et al. 1981, Booth 1985). This maintenance is critical for cell metabolism and growth as intracellular enzymes require specific $\mathrm{pH}$ levels to function efficiently. The current study shows that the bacterial community structure in Taylor Valley and Cape Hallett is correlated to soil $\mathrm{pH}$. This is consistent with a recent study comparing five soil types across Victoria Land that identified Deinococcus/Thermus and Gammaproteobacteria as the dominant bacterial groups in neutral to alkaline soils while Acidobacteria, Bacteroidetes, and Candidate TM7 dominated extremely alkaline soils, indicating that soils with different $\mathrm{pH}$ levels harbour different bacterial communities (Aislabie et al. 2008). Fierer \& Jackson (2006) also found that $\mathrm{pH}$ was correlated with bacterial community structure and that $\mathrm{pH}$ was the best predictor of bacterial richness and diversity in a study of ninety-eight soil samples from different ecosystems across North and South America. They found that neutral soils tended to have higher bacterial richness and diversity compared to acidic and alkaline soils, although not many alkaline soils were included as soils with $\mathrm{pH}$ levels greater than 8.5 are rare globally (Fierer \& Jackson 2006). This agrees with our finding that the alkaline soils of Taylor Valley tended to have fewer bacterial OTUs than the more acidic Cape Hallett soils, though this is conflated with other soil properties that influence both $\mathrm{pH}$ and habitat suitability, e.g. organic matter content and water content.

The bacterial community structure from eighty soil samples in Taylor Valley and Cape Hallett was also correlated to soil moisture. The availability of liquid water is believed to be the most important driving factor in the distribution and abundance of life in Antarctica (Kennedy 1993). The lack of biologically available water inhibits activity and growth even in the presence of adequate nutrients and selects for desiccation tolerant species (Billi \& Potts 2002). In this study, we collected soil samples from transects in areas designated as "high" or "low" productivity a priori based on the presence of visible phototrophs at the soil surface. The objective was to collect soil samples with varying soil moisture content as algae, moss, and lichens tend to grow in areas with higher soil moisture (Broady 1996, Broady \& Weinstein 1998). While Cape Hallett soils had significantly higher soil moisture than Taylor Valley soils, we did not discern a significant difference in soil moisture between high and low productivity transects within sites. 
However, the moisture of individual soil samples within sites is variable and is positively correlated with bacterial community structure, indicating that soil moisture content is patchy and influences microbial communities over fine spatial scales.

Just as there are both unique and shared soil chemistry values between Cape Hallett and Taylor Valley, there are both unique and shared bacterial community members despite the considerable distance and latitudinal difference between the sites. This is in agreement with the previous study that used the DGGE molecular fingerprinting method (Barrett et al. 2006a) that found both unique and shared microbial signatures at Taylor Valley and Luther vale, a site close to Cape Hallett. The presence of shared taxa among geographically distant soils separated by large ice sheets suggests that differences in the microbial communities are due to local variation in abiotic soil characteristics (intrinsic factors) rather than limitations of dispersion or regional characteristics (extrinsic factors).

Bacterial communities from Taylor Valley and Cape Hallett did not cluster tightly together based on geographical distance, suggesting that these communities are being influenced by either contemporary or historical environmental conditions. Where clear linkages between bacterial communities and modern soil physicochemical parameters are lacking, the biogeographic structure of the communities may be explained by abiotic factors not measured in this study (such as major ions or heavy metals), by the presence of generalist taxa, or by a legacy of past environmental conditions (i.e. glacial events). While all soils are products of past conditions, the paucity of modern sources of organic nutrients in Antarctic soils makes them particularly sensitive to this legacy effect (Barrett et al. 2006b). Another significant challenge to studying the effect of modern environmental conditions on microbial diversity in Antarctic habitats is the persistence of metabolically inactive cells. The very dry and cold climate can preserve dead or inactive cells as well as free DNA for long periods of time (Ah Tow \& Cowan 2005), thereby masking the effects of contemporary conditions. However, the differences seen between the Antarctic sites surveyed in this study and in previous studies (Barrett et al. 2006a, Niederberger et al. 2008) suggest that broad scale uniform wind-driven distribution of taxa does not take place.

Despite the limitations of molecular fingerprinting techniques and the unique challenges presented by the ecology of Antarctic terrestrial systems, this study and others like it contribute to the growing body of work uncovering the biogeography of microbial communities and provides baseline data for future monitoring through the Latitudinal Gradient Project. The simplified food webs and lack of vascular plants in polar desert communities allow us to identify which environmental variables have the greatest impact on the diversity and distribution of the unseen microbial majority (Whitman et al. 1998) which makes up most of the biomass in Antarctic terrestrial ecosystems. Determining the environmental drivers of microbial community structure and mapping microbial diversity throughout Victoria Land is critical for the identification of potential hotspots that may require special biosecurity consideration.

\section{Acknowledgements}

This work was supported by the National Science Foundation (OPP \#02-29836 to JEB and SCC and OPP \# 0739648 and 0632250 to SCC) and the McMurdo Long Term Ecological Research Project (OPP \#98-10219). Logistical support was provided by Antarctica New Zealand as part of the Latitudinal Gradient Project, Raytheon Polar Services and Petroleum Helicopters Inc. Special thanks to Shulamit Gordon, Gus McAllister and Rachel Brown of Antarctica New Zealand for field and logistical support. The authors wish to thank B. Kingham, University of Delaware Sequencing and Genotyping Center for technical support. We thank the referees for their comments.

\section{References}

Aн Tow, L. \& Cowan, D. 2005. Dissemination and survival of nonindigenous bacterial genomes in pristine Antarctic environments. Extremophiles, 9, 385-389.

Aislabie, J., Jordan, S., Ayton, J., Klassen, J.L., Barker, G.M. \& Turner, S. 2009. Bacterial diversity associated with ornithogenic soil of the Ross Sea region, Antarctica. Canadian Journal of Microbiology, 55, 21-36.

Aislabie, J.M., Jordan, S. \& Barker, G.M. 2008. Relation between soil classification and bacterial diversity in soils of the Ross Sea region, Antarctica. Geoderma, 144, 9-20.

Barrett, J.E., Gooseff, M.N. \& TaKacs-Vesbach, C.D. 2009. Spatial variation in active-layer geochemistry across hydrologic margins in polar desert ecosystems. Hydrology and Earth System Science, 13, 2349-2358.

Barrett, J.E., Virginia, R.A., Wall, D.H., Cary, S.C., Adams, B.J., Hacker, A.L. \& Aislabie, J.M. 2006a. Co-variation in soil biodiversity and biogeochemistry in northern and southern Victoria Land, Antarctica. Antarctic Science, 18, 535-548.

Barrett, J.E., Virginia, R.A., Hopkins, D.W., Aislabie, J., Bargagli, R., Bockheim, J.G., Campbell, I.B., Lyons, W.B., Moorhead, D.L., Nkem, J.N., Sletten, R.S., Steltzer, H., Wall, D.H. \& Wallenstein, M.D. 2006b. Terrestrial ecosystem processes of Victoria Land, Antarctica. Soil Biology and Biochemistry, 38, 3019-3034.

Billi, D. \& Potts, M. 2002. Life and death of dried prokaryotes. Research in Microbiology, 153, 7-12.

Bоотн, I.R. 1985. Regulation of cytoplasmic pH in bacteria. Microbiology and Molecular Biology Reviews, 49, 359-378.

Broady, P.A. 1996. Diversity, distribution and dispersal of Antarctic terrestrial algae. Biodiversity and Conservation, 5, 1307-1335.

Broady, P.A. \& Weinstein, R.N. 1998. Algae, lichens and fungi in La Gorce Mountains, Antarctica. Antarctic Science, 10, 376-385.

Burkins, M.B., Virginia, R.A., Chamberlain, C.P. \& Wall, D.H. 2000. Origin and distribution of soil organic matter in Taylor Valley, Antarctica. Ecology, 81, 2377-2391.

Campbell, I.B. \& Claridge, G.G.C. 1982. The influence of moisture on the development of soils of the cold deserts of Antarctica. Geoderma, 28, 221-238.

Cardinale, M., Brusetti, L., Quatrini, P., Borin, S., Puglia, A.M., Rizzi, A., Zanardini, E., Sorlini, C., Corselli, C. \& Daffonchio, D. 2004. Comparison of different primer sets for use in automated ribosomal intergenic spacer analysis of complex bacterial communities. Applied and Environmental Microbiology, 70, 6147-6156. 
Cary, S.C., McDonald, I.R., Barrett, J.E. \& Cowan, D.A. 2010. On the rocks: the microbiology of Antarctic Dry Valley soils. Nature Reviews Microbiology, 8, 129-138.

Clarke, K.R. 1993. Non-parametric multivariate analyses of changes in community structure. Austral Ecology, 18, 117-143.

Clarke, K.R. \& Gorley, R.N. 2006. PRIMER v6: User manual. Plymouth, UK: Plymouth Marine Laboratory.

DieTZ, E.J. 1983. Permutation tests for association between two distance matrices. Systematic Zoology, 32, 21-26.

Doran, P.T., McKay, C.P., Clow, G.D., Dana, G.L., Fountain, A.G., Nylen, T. \& Lyons, W.B. 2002. Valley floor climate observations from the McMurdo Dry Valleys, Antarctica, 1986-2000. Journal of Geophysical Research, 107, 4772-4784.

DuphoRn, K. 1981. Physiographical and glaciogeological observations in north Victoria Land, Antarctica. Geologische Jahrbuch, B41, 89-109.

FiereR, N. \& JACKSON, R.B. 2006. The diversity and biogeography of soil bacterial communities. Proceedings of the National Academy of Sciences, 103, 626-631.

Fisher, M.M. \& TRIPLETT, E.W. 1999. Automated approach for ribosomal intergenic spacer analysis of microbial diversity and its application to freshwater bacterial communities. Applied and Environmental Microbiology, 65, 4630-4636.

Fuhrman, J.A., Hewson, I., Schwalbach, M.S., Steele, J.A., Brown, M.V. \& NAEEM, S. 2006. Annually reoccurring bacterial communities are predictable from ocean conditions. Proceedings of the National Academy of Sciences, 103, 13 104-13 109.

Gower, J.C. 1971. A general coefficient of similarity and some of its properties. Biometrics, 27, 857-871.

Green, J.L., Holmes, A.J., Westoby, M., Oliver, I., Briscoe, D., Dangerfield, M., Gillings, M. \& Beattie, A.J. 2004. Spatial scaling of microbial eukaryote diversity. Nature, 432, 747-750.

Hewson, I. \& Fuhrman, J. 2006. Improved strategy for comparing microbial assemblage fingerprints. Microbial Ecology, 51, 147-153.

Hogg, I.D., Craig Cary, S., Convey, P., Newsham, K.K., O’Donnell, A.G., Adams, B.J., Aislabie, J., Frati, F., Stevens, M.I. \& Wall, D.H. 2006. Biotic interactions in Antarctic terrestrial ecosystems: are they a factor? Soil Biology and Biochemistry, 38, 3035-3040.
Howard-Williams, C., Peterson, D., Lyons, W.B., Cattaneo-Vietti, R. \& GoRDON, S. 2006. Measuring ecosystem response in a rapidly changing environment: the Latitudinal Gradient Project. Antarctic Science, 18, $465-471$.

KENNEDY, A.D. 1993. Water as a limiting factor in the Antarctic terrestrial environment: a biogeographical synthesis. Arctic and Alpine Research, 25, 308-315.

Legendre, P. \& Legendre, L. 1998. Numerical ecology. Amsterdam: Elsevier Science, $853 \mathrm{pp}$.

MadigAn, M.T. \& MartinKo, J.M. 2006. Brock biology of microorganisms. Upper Saddle River, NJ: Pearson Prentice Hall, 992 pp.

Michalski, G., Bockheim, J.G., Kendall, C. \& Thiemens, M. 2005. Isotopic composition of Antarctic Dry Valley nitrate: implications for $\mathrm{NO}_{\mathrm{y}}$ sources and cycling in Antarctica. Geophysical Research Letters, 32, 1-4.

Niederberger, T.D., McDonald, I.R., Hacker, A.L., Soo, R.M., Barrett, J.E., Wall, D.H. \& CARY, S.C. 2008. Microbial community composition in soils of northern Victoria Land, Antarctica. Environmental Microbiology, 10, 1713-1724.

Nocker, A., Burr, M. \& CAMPer, A. 2007. Genotypic microbial community profiling: a critical technical review. Microbial Ecology, 54, 276-289.

Padan, E., Zilberstein, D. \& Schuldiner, S. 1981. pH homeostasis in bacteria. Biochimica et Biophysica Acta - Reviews on Biomembranes, 650, 151-166.

Smith, J.J., Tow, L., Stafford, W., Cary, C. \& Cowan, D.A. 2006. Bacterial diversity in three different Antarctic cold desert mineral soils. Microbial Ecology, 51, 1-9.

TReOnIs, A.M., WaLL, D.H. \& VIRGINIA, R.A. 1999. Invertebrate biodiversity in Antarctic Dry Valley soils and sediments. Ecosystems, 2, 482-492.

UGolini, F.C. \& Bоскнеiм, J.G. 2008. Antarctic soils and soil formation in a changing environment: a review. Geoderma, 144, 1-8.

WaLL, D.H. \& ViRgINIA, R.A. 1999. Controls on soil biodiversity: insights from extreme environments. Applied Soil Ecology, 13, 137-150.

Whitman, W.B., Coleman, D.C. \& Wiebe, W.J. 1998. Prokaryotes: the unseen majority. Proceedings of the National Academy of Sciences, 95, 6578-6583.

Yergeau, E., Newsham, K.K., Pearce, D.A. \& Kowalchuk, G.A. 2007. Patterns of bacterial diversity across a range of Antarctic terrestrial habitats. Environmental Microbiology, 9, 2670-2682. 